\title{
Human endogenous retrovirus K (HERV-K) transcripts detection in babies exposed to HIV-1 during pregnancy
}

\author{
Camila M Romano ${ }^{1 *}$, Danielly Oliveira', Deborah Gerhardt ', Luiz HS Nali', Giovana S Caleiro ${ }^{1}$, Cristina F Nunes ${ }^{1}$, \\ Fernanda Granato ${ }^{1}$, Fabiana B do Carmo ${ }^{2}$, Regina CM Succi², Daisy M Machado ${ }^{1,2}$
}

From 16th International Conference on Human Retroviruses: HTLV and Related Viruses

Montreal, Canada. 26-30 June 2013

Human endogenous retroviruses of the K family (HERV-K) are among the most recently integrated retroviruses in the human genome. HERV-K mRNA can be detected in normal tissues, but its expression is remarkably enhanced in HIV-1 infected patients due to HIV-Tat induction. Additionally, HERV-K activity stimulates both humoral and cellular responses, suggesting that HERV-specific immunity may contribute to the control of HIV-1 replication in adults. Recently, it was reported that vertically infected children has HERV specific T-cell response.

Since most children born from HIV infected mothers (65-85\%) do not get infected despite the possible intrautero contact with the virus, we evaluated the HERV-K activity in non-infected babies born from: HIV-1 positive mothers (HIV-exposed), and from non-HIV-1 mothers (non-exposed). Peripheral blood mononuclear cells (PBMC) were obtained from 11 babies between 1 to 11-months-old and also from their respective HIV-1 infected mothers. Exposed babies were not breastfed and had no HIV or other viral infection. HERV-K (HML-1-10) transcripts were screened by qRT-PCR, and the expression was evaluated through the absolute threshold-Ct normalized against B-Actin expression.

All babies presented some level of HERV-K expression that could not be differentiated between HIV-exposed and non-exposed groups. The expression was also similar according to the age and ethnic origin. Although all HIV-positive mothers have undetectable HIV-1 load, all but one expressed HERV-K. Thus, because all babies

\footnotetext{
* Correspondence: cmromano@usp.br

'Departamento de Moléstias Infecciosas e Parasitárias (LIMHC), Instituto de Medicina Tropical de São Paulo, Universidade de São Paulo, São Paulo, SP, Brazil

Full list of author information is available at the end of the article
}

investigated presented HERV-K activity despite the HIV-1 exposure, it is possible that HERV activity in babies could works as a primal immunological mechanism to dealing with the exogenous infectious agents.

\section{Funding}

This work was supported by FAPESP \#2011/13612-9 and \#2010/10619-0.

\section{Authors' details}

'Departamento de Moléstias Infecciosas e Parasitárias (LIMHC), Instituto de Medicina Tropical de São Paulo, Universidade de São Paulo, São Paulo, SP, Brazil. 'Disciplina de Infectologia Pediátrica da Escola Paulista de Medicina, Universidade Federal de São Paulo, São Paulo, SP, Brazil.

Published: 7 January 2014

doi:10.1186/1742-4690-11-S1-P134

Cite this article as: Romano et al:: Human endogenous retrovirus $\mathrm{K}$ (HERV-K) transcripts detection in babies exposed to HIV-1 during pregnancy. Retrovirology 2014 11(Suppl 1):P134.

Submit your next manuscript to BioMed Central and take full advantage of:

- Convenient online submission

- Thorough peer review

- No space constraints or color figure charges

- Immediate publication on acceptance

- Inclusion in PubMed, CAS, Scopus and Google Scholar

- Research which is freely available for redistribution 